\title{
Therapy of Peripartum Mental Disorders
}

\author{
Miodrag Stanković1,2, Jelena Stojanov³, Jovana Antonijević ${ }^{1}$ \\ ${ }^{1}$ University of Niš, Faculty of Medicine,Niš, Serbia \\ ${ }^{2}$ Centre for Mental Health Protection, Clinical Centre Niš, Niš, Serbia \\ 3Special Hospital for Psychiatric Diseases "Gornja Toponica", Niš, Serbia
}

\section{SUMMARY}

During the peripartum period, women are at a greater risk of developing a mental disorder or experiencing an exacerbation of the pre-existing mental disorders. Therapeutic interventions are based primarily on psychotherapy, but if the symptoms are severe and pose a risk to the mother and the child, then the use of drugs, hospitalization or electroconvulsive therapy is considered. Cognitive-behavioral psychotherapy is the first line of treatment in postpartum blues and postpartum depression, panic disorder, generalized anxiety disorder, and mild to moderate obsessive-compulsive disorder. More recent conceptions regarding the use of drugs during the postpartum period indicate that medications should be prescribed if the risk of using them is lower than the risk of complications caused by the symptoms of mental disorders. Nortriptyline or desipramine are recommended from the group of tricyclic antidepressants, but newer generation antidepressants are shown to be safer during pregnancy. Fluvoxamine, paroxetine and sertraline can be used in postpartum period during breastfeeding, while fluoxetine and citalopram should be avoided. The use of first-generation antipsychotics haloperidol and trifluoperazine is recommended in the antepartum period, during which some of second-generation antipsychotics such as quetiapine, olanzapine, risperidone and aripiprazole can also be used. Clozapine should be avoided during breast-feeding. The use of mood stabilizers during pregnancy requires a thorough knowledge of the recommendations, and it is not advised to use them during the postpartum if the patient is breastfeeding. From the group of benzodiazepines, it is recommended to uselorazepam. Every form of therapeutic approach has proven to be more effective in the presence of emotional support from partners and other family members.

Key words: peripartum, psychotherapy, pharmacotherapy

Corresponding author:

Miodrag Stanković

E-mail: doc.stankovic@mail.com 


\section{INTRODUCTION}

Disorders that occur during pregnancy or in the postpartum period are referred to as peripartum mental disorders. The postpartum period is described by most authors as a period of six months, a year at most, after giving birth $(1,2)$. The fifth revision of the Diagnostic and Statistical Manual for Mental Disorders (DSM-V) defines depression with peripartum-onset as an episode which occurs during pregnancy or within four weeks after the delivery (3). The new revision of the International Classification of Diseases (ICD-11) includes postpartum mental or behavioral disorders with and without psychosis (6E20) (4).

During the peripartum period, and especially in the postpartum period, women are at a greater risk of developing new mental disorders or experiencing exacerbations of preexisting mental disorders, which consequently impair the physical and mental health of the woman, as well as the functionality of the whole family (5 - 7).

The therapeutic approach to mental disorders of peripartum is a complex process which is the focus of numerous studies. All psychotropic medications enter the circulation of the fetus through the placenta. The latest findings in terms of use of drugs during the peripartum suggest that the medications should be used if the risk of their use is lower than the risk of developing complications caused by the symptoms of mental disorders.

\section{Therapy of peripartum depression}

A more modern approach to the treatment of postpartum depression implies that mild to moderately severe depression should be treated with psychotherapy, and moderate to severe depression should be treated with psychotherapy and antidepressants combined (8).

\section{Psychotherapy}

Cognitive-behavioral psychotherapy (CBT) and interpersonal psychotherapy (IPT) are shown to be the most efficient in the treatment of peripartum depression $(9,10)$. CBT focuses on adopting an adaptive way of thinking, behavior patterns or both, and results in positive changes in the emotional state. IPT focuses on improving communication and strengthening the relationship between partners in the peripartum period.

\section{Antidepressants}

Antidepressants are recommended when the symptoms of peripartum depression cannot be resolved by psychotherapy, when the symptoms are severe and pose a threat to the mother and child and thus require a faster treatment, or if such a treatment suits the patient (11). The use of these medications is indicated for the duration of six to twelve months, or more in women with a relapse of the disorder. Since the progression of pregnancy leads to a decrease in levels of all drugs in the mother's serum, most likely due to increased metabolic degradation in the liver and increased volume of distribution, it is sometimes necessary to increase the dose of the antidepressant (12). The risk of endometrial hyperplasia and thrombosis significantly limits the possibility of preventive intradermal administration of estrogen and progesterone (13). Benzodiazepines can be introduced into treatment for depression cautiously and according to the recommendations, when pathological anxiety and insomnia are present, and antipsychotic medications can be introduced when characteristic psychotic symptoms are present (14).

The degree of distribution of antidepressants differs and depends on the characteristics of the drug and the mother's physiology (15). Most women who are prescribed antidepressants stop taking them because of potential teratogenicity. It is known that women who take antidepressants during pregnancy are at a greater risk of developing hypertension, pre-eclampsia and postpartum hemorrhage. It is shown that the possible risk of relapse of depression is close to $70 \%$ in women who have stopped taking therapy during pregnancy (16). Untreated depression during pregnancy is associated with preterm labor and low birth weight of the child $(17,18)$.

When choosing an antidepressant for the treatment of peripartum depression, it is recommended to use the drug which has previously helped the patient.

From the group of tricyclic antidepressants (TCA), it is safer to use nortriptyline (optimal dose of 50$80 \mathrm{mg}$ per day) or desipramine (up to $200 \mathrm{mg}$ per day) during the peripartum period, because they exhibit a weaker anticholinergic and hypotensive effect than amitriptyline and imipramine. TCAs during pregnancy do not increase the risk of congenital anomalies but increase the risk of premature labor, and can lead to agitation, irritability and respiratory distress in the third trimester (19). The use of TCAs is generally avoided after the delivery, since they pass into breast milk, especially in the case of doxepin, which, at a maximum daily dose of $75 \mathrm{mg}$, can lead to excessive sedation and respiratory 
depression of the infant (19). The prolongation of the QT interval and ventricular tachycardia of the type "torsades de pointes" were observed in neonates of mothers who were treated with clomipramine (at a dose of $100 \mathrm{mg}$ to $150 \mathrm{mg}$ per day) and amitriptyline (at a dose of $25 \mathrm{mg}$ to $100 \mathrm{mg}$ per day) in the first trimester and during the postpartum period (20).

Drugs from the group of selective serotonin uptake inhibitors (SSRI) have beneficial effects in the treatment of peripartum depression. When taken in late pregnancy, SSRIs may increase the risk of pulmonary hypertension in newborns and of postpartum bleeding in mothers (21). Sertraline, fluoxetine or citalopram at initial doses of $20 \mathrm{mg}$, with gradual dosage titration, are often recommended as a first-line therapy, since they pass into breast milk in minimal concentrations (22). Citalopram (at a maximum dose of $40 \mathrm{mg}$ ), escitalopram (at a maximum dose of $20 \mathrm{mg}$ ) and sertraline (at a maximum dose of $100 \mathrm{mg}$ ) are shown to be the safest during pregnancy, while fluvoxamine (at a daily dose of up to $300 \mathrm{mg}$ ), paroxetine (at a daily dose of up to $30 \mathrm{mg}$ ) and sertraline (at a daily dose of up to $100 \mathrm{mg}$ ) are recommended during the postpartum period in women who breast feed (23).

Use of fluoxetine (at a daily dose of up to $40 \mathrm{mg}$ ) is advised in the first trimester of pregnancy for mild forms of depression, but caution is advised when using this medication in women who breast feed, as it disrupts the rhythm of sleep and leads to increased tearfulness of the child, and for that reason it should be used at the maximum daily dose of $20 \mathrm{mg}$ during that period of time (24). High doses of paroxetine (30 $\mathrm{mg}$ to $60 \mathrm{mg}$ per day) in the first trimester are associated with atrial and ventricular septal defects and pulmonary valve stenosis in children (25). If adverse effects occur during therapy with paroxetine or sertraline in the peripartum period, the drug of choice is citalopram in the initial therapeutic doses (26).

Ketamine is not shown to be effective in therapy of postpartum depression (27). Recent studies show that the use of optimal doses of reboxetine, bupropion and mirtazapine in the antepartum period do not lead to congenital malformations, but these medications, as well as SSRIs, can be associated with spontaneous abortion (28). The use of bupropion in the first trimester at a daily dose of up to $250 \mathrm{mg}$ increases the risk of ventricular septal defects (29) and hyperkinetic disorder (ADHD) in children (30). The use of venlafaxine and duloxetine in the second trimester is associated with low birth weight of the child, although there are dilemmas regarding the dose, which makes it necessary to determine the dosage of the drug (31).

Monoamine oxidase inhibitors (MAOIs) should be avoided in the peripartum period due to the high risk of fetal congenital malformations, as well as sedation, insomnia and hypertensive crises of the mother. Recent data from literature indicate the absence of teratogenic potential of moclobemide used in the antepartum period in full therapeutic dose (28).

When suicidal ideas and intentions or severe psychotic symptomatology are present, along with a weak response to pharmacotherapy, it is necessary to consider hospitalization and the application of electroconvulsive therapy $(32,33)$.

\section{Electroconvulsive therapy (ECT)}

ECT can be used during the peripartum in the treatment of depression and psychosis. The fetus is very briefly exposed to the effect of ECT during pregnancy, and the result is achieved faster than with other forms of treatment, which makes this method useful and effective. ECT is a reliable method during the lactation period, because the drugs used during the procedure (myorelaxants and sedatives) pass into milk in minimal quantities. ECT is particularly worth considering in case there is a need for a fast resolution of symptoms and in resistant forms when there is lack of response to monopharmacotherapy. In these cases, application of ECT is advised before or even instead of a combination of medications $(32,33)$.

\section{Therapy of peripartum psychosis}

The therapy of peripartum psychosis involves the application of therapy only in a hospital setting, where it is necessary to use both antipsychotic, mood stabilizer, sedative and/or ECT.

Antipsychotics and all antiparkinsonics should, if possible, be avoided during the first trimester of pregnancy. In the event that the use of these medications is unavoidable, the lowest possible dose needed to achieve the effect should be used and depot forms of antipsychotics should be avoided.

Use of antipsychotics. The use of first generation of antipsychotic drugs, such as haloperidol or trifluoperazine, is advised in the antepartum period. These medications have a minimal teratogenic risk (34) and are not expected to cause more adverse effects such as orthostatic hypotension, sedation, tachycardia, or constipation (35) compared to second-generation 
antipsychotics. When used during pregnancy, their adverse effects include premature labor and low birth weight of the child (36), as well as the occurrence of neonatal dyskinesia (37) and jaundice (38).

The use of second-generation antipsychotics during pregnancy is associated with increased birth weight, gestational diabetes (38), and a mild risk of cardiac septal defect. However, these medications are important because they can stabilize the mother's mood and do not cause congenital malformations. The data indicate that clozapine has the potential to reduce the threshold for epileptic seizures, as well as to cause fatal agranulocytosis (39).

Available data indicate that it is safe to use quetiapine (at a daily dose of up to $400 \mathrm{mg}$ ), olanzapine (at a daily dose of up to $25 \mathrm{mg}$ ) and aripiprazole (at a daily dose of $20 \mathrm{mg}$ ) during the reproductive period (40), as well as risperidone (at a daily dose of $4-6 \mathrm{mg}$ ) (41). Most recent studies conducted on small samples indicate that clozapine used in pregnancy at a dose of $100 \mathrm{mg}$, partially passes the placental barrier, similarly to other atypical antipsychotics, but no acute toxic effects in newborns who were exposed in utero (42) have been reported. The use of antipsychotics immediately prior to delivery increases the risk of the newborn developing extrapyramidal symptoms, when routine prophylaxis is not recommended. If the symptoms are very pronounced, it is recommended to administer antihistamine diphenhydramine.

All antipsychotics are excreted in milk, so it is advisable that during the period of breast-feeding treatment should be continued with the antipsychotic used during pregnancy. Women who take clozapine should be advised not to breast feed their babies, since its excretion is up to four times higher than allowed (43), and carries the risk of fatal agranulocytosis in the baby (44). When starting postpartum antipsychotic treatment, olanzapine or quetiapine should be considered (45).

Use of mood stabilizers. During pregnancy, the use of lithium may be harmful, therefore it is recommended to use it in small doses and without a sudden increase in dosage. Plasma concentrations of up to $1.0 \mathrm{mmol} / \mathrm{L}(46)$ are required to maintain antidepressant activity. The period with the highest risk is from the second to sixth week after conception, which is the period when pregnancy is not yet recognized in most cases (47). Lithemia immediately prior to delivery should not exceed $0.9 \mathrm{mEq} / \mathrm{L}$ due to potential neonatal toxicity (48). Since it is necessary to increase the dose of lithium during pregnancy in order to prevent symptoms from manifesting, there is a risk of cyanotic and hypotonic babies ("floppy baby" syndrome), because lithium passes the placental barrier completely and the baby's kidneys cannot eliminate it. Atrial and ventricular septal defects, hypotonia, lethargy and arrhythmias are common. Women on therapy with lithium are advised not to breast feed their children.

The use of mood stabilizers during the antepartum period is associated with autism spectrum disorders and with several neurocognitive deficits which occur during childhood (49). Carbamazepine, although relatively safe during breastfeeding at a daily dose of 8$12 \mu \mathrm{g} / \mathrm{ml}$, increases the risk of craniofacial and digital abnormalities and disorders in children of up to six years of age (50), which is why psychomotor monitoring with blood count control is necessary. Sodium-valproate used in the first trimester of pregnancy has a teratogenic effect and causes craniofacial and urogenital malformations, as well as malformations of extremities, and slows down the psychomotor development of the baby. The use of sodium-valproate in the first trimester is associated with the delay in walk and speech development and low intellectual ability, in comparison to the use of carbamazepine and lamotrigine. In case the use of sodium-valproate or carbamazepine is inevitable, the use of 1-4mg of folic acid per day is advised in order to prevent neural-tube defect ("Fetal valproate syndrome") (51). If sodium-valproate does not exceed toxic limits, it is safe during breastfeeding (52). Phenobarbitone (53) is not recommended during the lactation period.

The use of benzodiazepines in the third trimester of pregnancy is associated with premature birth, low birth weight, feeding problems, respiratory distress and myoclonic convulsions in newborns $(54,55)$. It is unlikely that the episodic use of short-acting benzodiazepines, especially lorazepam, is harmful, as well as the use of sedative antihistamine medication promethazine.

\section{Therapy of peripartumanxiety disorders}

The prevention and treatment of new anxiety disorders or exacerbations of preexisting anxiety disorders in peripartum is increasingly becoming the subject to numerous research.

\section{Psychotherapy}

Cognitive Behavioral Psychotherapy (CBT) is often described as a preventative method and a therapy of choice for panic disorder (PD) and generalized anxiety disorder (GAP) during pregnancy (56). It is also described as the first-line therapy for mild to moderate 
obsessive-compulsive disorder (OCD) in peripartum, and is combined with SSRIs in cases of severe forms of the disorder (57). Applied immediately after childbirth with complications, it reduces the risk of post-traumatic stress disorder (PTSD) (58).

\section{Pharmacotherapy}

Psychoeducation of pregnant women and their partners makes this treatment more acceptable to them (59). In the case of PD and GAP, low dose SSRIs are the first-line therapy, and if these previously have not been effective, serotonin and noradrenaline (SNRI) inhibitors should be introduced, with regular blood pressure monitoring (60), or low doses of imipramine. Short-term use of benzodiazepines during the peripartum period is sometimes necessary in cases of more severe panic attacks, but these medications should be discontinued after a short period of time, particularly when they are combined with antidepressants, since they can cause complications during the delivery and hypertonia, hyperreflexia, tremor and congenital malformations in children $(61,62,63)$.

In the case of obsessive-compulsive disorder which occurs during the lactation period, treatment should start with higher doses of SSRIs, specifically: sertraline (at a daily dose of up to $200 \mathrm{mg}$ ), fluvoxamine (at a daily dose of $300 \mathrm{mg}$ ), paroxetine (at a daily dose of $30-60 \mathrm{mg}$ ) or escitalopram (at a daily dose of up to 20 $\mathrm{mg}$ ) (64), while fluoxetine and citalopram should be avoided (65).

Benzodiazepines are excreted in breast milk in low concentrations, and although they may cause sedation of the baby (especially in combination with anti depressants), they are not contraindicated during breastfeeding. The recommended drug is lorazepam at a maximum daily dose of up to $7.5 \mathrm{mg}(8)$.

\section{Therapy of postpartum blues}

Sleep disorders, sleep deprivation due to nursing and physical exhaustion due to the adaptation to the baby's feeding and sleep rhythm have significant influence on this condition (66). Under these circumstances, the postpartum blues passes only with the emotional support of the partner and family, sleep regulation and more rest. Domiciliary care, combined with the use of cognitive-behavioral psychotherapy (CBT) and supportive psychotherapy, may further mitigate the symptomatology (67).

\section{CONCLUSION}

Mental disorders in women during the peripartum period are common and are mostly unrecognized in a timely manner, and consequently cause changes in the psychological and social aspects of the lives of all family members. Treatment of peripartum mental disorders can significantly lower the rate of general family morbidity and mortality, bearing in mind that the disorders endanger women, fetuses, newborns and partner relationships. The choice of therapy depends on the type and intensity of the symptoms, the presence of the partner and the support of family members, as well as on the assessment that the risk-benefit ratio is disproportionally in favor of the benefit. For optimum dosage regimen during the peripartum, it is necessary to know the pharmacokinetic and pharmacodynamic profile of the drug which is used, and therapeutic monitoring is necessary in order to maintain the effective drug concentrations. 


\section{References}

1. O'Hara MW, Wisner KL. Perinatal mental illness: definition, description and aetiology. Best Pract Res Clin Obstet Gynaecol 2014;28(1):3-12.

https://doi.org/10.1016/j.bpobgyn.2013.09.002

2. Kimura $\mathrm{Y}, \mathrm{Kato} \mathrm{T}$, Miyata $\mathrm{H}$ et al. Factors associated with increased levels of brain natriuretic peptide and cardiac troponin I during the peripartum period. PLoS One 2019 7;14(2).

https://doi.org/10.1371/journal.pone.0211982

3. American Psychiatric AssociationAmerican Psychiatric Association. Diagnostic and Statistical Manual of Mental Disorders, Fifth Edition. Diagnostic and Statistical Manual of Mental Disorders, Fifth Edition. Arlington, VA: American Psychiatric Press, Inc; 2013; 271-80.

https://doi.org/10.1176/appi.books.9780890425596

4. WHO. International Statistical Classification of Diseases and Related Health Problems, $11^{\text {th }}$ Revision: ICD-11. World Health Organization, Geneva, June 2018.

\section{https://doi.org/10.1071/SH17086}

5. Schapir L, Zalsman M. Bipolar disorder and severe mood dysregulation in children and adolescents. Harefuah 2008;147:526-31.

6. Brockington I. Postpartum psychiatric disorders. Lancet 2004; 363(9405):303-10.

https://doi.org/10.1016/S0140-6736(03)15390-1

7. Miljković S, Stanković M, Lakić A. Psihijatrijski poremećaji tokom trudnoće i postpartalnog perioda. U: Miladinovića P. (ur.): Urgentna stanja u ginekologiji i perinatologiji, Medicinski fakultet u Nišu 2006; 191227.

8. Guille C, Newman R, Fryml LD et al. Management of Postpartum Depression. J Midwifery Womens Health 2013; 58(6):643-53.

https://doi.org/10.1111/jmwh.12104
9. Nillni YI, Mehralizade A, Mayer L et al. Treatment of depression, anxiety, and trauma-related disorders during the perinatal period: A systematic review. 2018; 66:136-48.

https://doi.org/10.1016/j.cpr.2018.06.004

10. Morrell CJ, Sutcliffe P, Booth A et al. A systematic review, evidence synthesis and meta-analysis of quantitative and qualitative studies evaluating the clinical effectiveness, the cost-effectiveness, safety and acceptability of interventions to prevent postnatal depression. Health Technology Assessment (Winchester,England) 2016; 20(37):1-414.

https://doi.org/10.3310/hta20370

11. Fournier JC, DeRubeis RJ, Hollon SD et al. Antidepressant Drug Effects and Depression Severity. A Patient-Level Metaanalysis. JAMA 2010; 303(1):4753.

https://doi.org/10.1001/jama.2009.1943

12. Lam RW, Kennedy SH, Parikh SV. Canadian Network for Mood and Anxiety Treatments (CANMAT) 2016 clinical guidelines for the management of adults with major depressive disorder: introduction and methods. Can J Psychiatry 2016; 61:506-9.

https://doi.org/10.1177/0706743716659061

13. Khan MM. Translational Significance of Selective Estrogen Receptor Modulators in Psychiatric Disorders. Int J Endocrinol 2018.

https://doi.org/10.1155/2018/9516592

14. Kim DR, Epperson $\mathrm{CN}$, Weiss $\mathrm{AR}$ et al. Pharmacotherapy of postpartum depression: an update. Expert Opin Pharmacother. 2014; 15(9):122334 .

https://doi.org/10.1517/14656566.2014.911842

15. Mirkin BL. Drug disposition and therapy in the developing human being. Pediatr Ann 1976; 5(9):542-57.

https://doi.org/10.3928/0090-4481-19760901-05 
16. Cohen LS. Relapse of major depression during pregnancy in women who maintain or discontinue antidepressant treatment. JAMA 2006; 295:499-507. https://doi.org/10.1001/jama.295.5.499

17. Jarde A. Neonatal outcomes in women with untreated antenatal depression compared with women without depression: a systematic review and meta-analysis. JAMA Psychiatry 2016; 73:826-37.

https://doi.org/10.1001/jamapsychiatry.2016.0934

18. Damjanović M, Stanković M. Uticaj konstelativnih faktora porodilje na pojavu i karakteristike postpartalne depresije. Acta Medica Medianae 2007; 46-4.

19. Yoshida K, Smith B, Kumar R. Psychotropic drugs in mother's milk: a comprehensive review of assay methods, pharmacokinetics and of safety of breastfeeding. J Psychopharmacol 1999, 13:64-80.

https://doi.org/10.1177/026988119901300108

20. Fukushima N. A neonatal prolonged QT syndrome due to maternal use of oral tricyclic antidepressants. Eur J Pediatr 2016; 175:1129-32.

https://doi.org/10.1007/s00431-016-2722-x

21. Davis RL. Risks of congenital malformations and perinatal events among infants exposed to antidepressant medications during pregnancy. Pharmacoepidemiol Drug Saf 2007; 16:1086-94.

https://doi.org/10.1002/pds.1462

22. Hanley GE. Postpartum hemorrhage and use of serotonin reuptake inhibitor antidepressants in pregnancy. Obstet Gynecol 2016;127:553-61.

https://doi.org/10.1097/AOG.0000000000001200

23. Orsolini L, Bellantuono C. Serotonin reuptake inhibitors and breastfeeding: a systematic review. Hum Psychopharmacol 2015; 30: 4-20.

https://doi.org/10.1002/hup.2451

24. Pirec V. Postporođajni emocionalni poremećaji. Seminar Instituta za mentalno zdravlje, Beograd, 2003.

25. Berard A. The risk of major cardiac malformations associated with paroxetine use during the first trimester of pregnancy: a systematic review and meta-analysis. Br J Clin Pharmacol 2016; 81:589-604. https://doi.org/10.1111/bcp.12849
26. Faruk U. Better Tolerance of Citalopram in a Breastfed Infant Who Could Not Tolerate Sertraline and Paroxetine. Breastfeed Med 2018; 13(1):89-90.

https://doi.org/10.1089/bfm.2017.0168

27. Xu Y, Li Y, Huang X et al. Single bolus low-dose of ketamine does not prevent postpartum depression: a randomized, double-blind, placebocontrolled, prospective clinical trial. Arch Gynecol Obs 2017, 295:1167-74.

https://doi.org/10.1007/s00404-017-4334-8

28. Smit M. Mirtazapine in pregnancy and lactation a systematic review. Eur Neuropsychopharmacol 2016; 26:126-35.

https://doi.org/10.1016/j.euroneuro.2015.06.014

29. Louik C. First trimester exposure to bupropion and risk of cardiac malformations. Pharmacoepidemiol Drug Saf 2014; 23:1066-75. https://doi.org/10.1002/pds.3661

30. Figueroa R. Use of antidepressants during pregnancy and risk of attention deficit/hyperactivity disorder in the offspring. J Dev Behav Pediatr 2010; 31:641-8.

https://doi.org/10.1097/DBP.0b013e3181e5ac93

31. Hoog SL. Duloxetine and pregnancy outcomes: safety surveillance findings. Int J Med Sci 2013; 10(4):413-9.

https://doi.org/10.7150/ijms.5213

32. Ward HB, Fromson JA, Cooper JJ et al. Recommendations for the use of ECT in pregnancy: literature review and proposed clinical protocol. Arch Womens Ment Health 2018;21(6):715-22. https://doi.org/10.1007/s00737-018-0851-0

33. Rundgren S, Brus O, Bûave U et al. Improvement of postpartum depression and psychosis after electroconvulsive therapy: a population-based study with a matched comparison group. J Affect Disord 2018 1;235:258-64.

https://doi.org/10.1016/j.jad.2018.04.043

34. Gentile S. Antipsychotic therapy during early and late pregnancy. A systematic review. Schizophr Bull 2010; 36:518-44.

https://doi.org/10.1093/schbul/sbn107 
35. Miller LJ. Pharmacotherapy during perinatal period. The Hatherligh Guide to Psychopharmacology. New York: Haterleigh press 1999.

36. Habermann F. Atypical antipsychotic drugs and pregnancy outcome: a prospective, cohort study. J Clin Psychopharmacol 2013; 33:453-62.

https://doi.org/10.1097/JCP.0b013e318295fe12

37. Collins KO. Maternal haloperidol therapy associated with dyskinesia in a newborn. Am J Health Syst Pharm 2003; 60:2253-5.

https://doi.org/10.1093/ajhp/60.21.2253

38. Boden R. Antipsychotics during pregnancy: relation to fetal and maternal metabolic effects. Arch Gen Psychiatry 2012; 69:715-21.

https://doi.org/10.1001/archgenpsychiatry.2011.1870

39. Gentile S. Antipsychotic therapy during early and late pregnancy. A systematic review. Schizophr Bull 2010; 36:518-44.

https://doi.org/10.1093/schbul/sbn107

40. Westin AA, Brekke M, Molden E et al. Treatment With Antipsychotics in Pregnancy: Changes in Drug Disposition. Clin Pharmacol Ther 2018; 103(3):477-84. https://doi.org/10.1002/cpt.770

41. McAllister Williams RH, Baldwin DS, Cantwell $\mathrm{R}$, et al. British Association for Psychopharmacology consensus guidance on the use of psychotropic medication preconception, in pregnancy and postpartum. J Psychopharmacol 2017; 31(5):519-52. https://doi.org/10.1177/0269881117699361

42. Imaz ML, Oriolo G, Torra M et al. Clozapine Use During Pregnancy and Lactation: A Case-Series Report. Front Pharmacol 2018; 27;9:264.

https://doi.org/10.3389/fphar.2018.00264

43. Barnas C, Bergant A, Hummer M et al. Clozapine concentrations in maternal and fetal plasma, amniotic fluid and breast milk. Am J Psychol 1994;151:945.

https://doi.org/10.1176/ajp.151.6.945

44. Ericson A, Källén B, Wiholm B. Delivery outcome after the use of antidepressants in early pregnancy. Eur J Clin Pharmacol 1999, 55:503-8.

https://doi.org/10.1007/s002280050664
45. Aydin B. Olanzapine and quetiapine use during breastfeeding: excretion into breast milk and safe breastfeeding strategy. J Clin Psychopharmacol 2015; 35:206-8.

https://doi.org/10.1097//CP.0000000000000291

46. Westergren T. Probable topiramate induced diarrhea in a 2 month old breast fed child - a case report. Epilepsy Behav Case Rep 2014;2:22-3.

https://doi.org/10.1016/j.ebcr.2013.12.006

47. Bjornsson E. Hepatotoxicity associated with antiepileptic drugs. Acta Neurol Scand 2008;118:28190.

https://doi.org/10.1111/j.1600-0404.2008.01009.x

48. Zisook S, Burt V. Psychiatric Disorders During Pregnancy. Psychiatric Times, 2003; 20(1):17.

49. Meador KJ, Baker GA, Browning $\mathrm{N}$ et al. Cognitive function at 3 years of age after fetal exposure to antiepileptic drugs. N Engl J Med 2009; 360(16):1597-605.

https://doi.org/10.1056/NEIMoa0803531

50. Ornoy A, Cohen E. Outocome of childen born to epileptic mothers treated with carbamazepine during pregnancy. Arch Dis Child 1996;75:517-20. https://doi.org/10.1136/adc.75.6.517

51. Davanzo R. Benzodiazepine e allattamento materno. Medico e Bambino 2008; 27:109-14.

52. Chaudron LH, Jefferson JW. Mood stabilizers during breastfeeding: a review. J Clin Psychiatry 2000; 61:79-90.

https://doi.org/10.4088//CP.v61n0202

53. Pons G, Rey E, Matheson I. Excretion of psychoactive drugs into breast milk. Pharmacokinetic principles and recommendations. Clin Pharmacokinet 1994; 27(4): 270-89.

https://doi.org/10.2165/00003088-199427040-00003

54. Vitale SG, Lagana AS, Muscatello MR. Psychopharmacotherapy in pregnancy and breastfeeding. Obstet Gynecol Surv 2016; 71(12): 721-33. https://doi.org/10.1097/OGX.0000000000000369

55. Huybrechts KF, Bateman BT, Desai RJ. Risk of neonatal drug withdrawal after intrauterine co- 
exposure to opioids and psychotropic medications: cohort study. BMJ 2017;358:j3326.

https://doi.org/10.1136/bmi.j3326

56. Austin MP, Acland S, Frilingos $\mathrm{M}$ et al. Brief antenatal cognitive behavior therapy group intervention for the prevention of postnatal depression and anxiety: a randomized controlled trial. Affect Disord 2008; 105(1-3):35-44.

https://doi.org/10.1016/j.jad.2007.04.001

57. Koran LM, Hanna GL, Hollander E et al. American Psychiatric Association. Practice guideline for the treatment of patients with obsessivecompulsive disorder. Am J Psychiatry 2007; 164(7 Suppl):5-53.

58. De Schepper S, Vercauteren T, Tersago J et al. Post-traumatic stress disorder after childbirth and the influence of maternity team care during labour and birth: a cohort study. Midwifery 2016; 32:87-92. https://doi.org/10.1016/j.midw.2015.08.010

59. Prady SL, Hanlon I, Fraser LK et al. A systematic review of maternal antidepressant use in pregnancy and short- and long-term offspring's outcomes. Arch Womens Ment Health 2018;21(2):127-40.

https://doi.org/10.1007/s00737-017-0780-3

60. Wikner BN, Stiller CO, Bergman U et al. Use of benzodiazepines and benzodiazepine receptor agonists during pregnancy: neonatal outcome and congenital malformations. Pharmacoepidemiol Drug Saf 2007; 16(11):1203-10.

https://doi.org/10.1002/pds.1457

61. Yonkers KA, Gilstad-Hayden K, Forray A et al. Association of panic disorder, generalized anxiety disorder, and benzodiazepine treatment during pregnancy with risk of adverse birth outcomes. JAMA Psychiatry 2017;74(11):1145-52.

https://doi.org/10.1001/jamapsychiatry.2017.2733

62. Krstić D, Pop-Trajković S, Stanković M et al. The influence of prenatal stress on neurobehavioral development of fetus and child. Acta Facultatis Medicae Naissensis 2007; 24(3)113-20.

63. Kronenfeld N, Berkovitch M, Berlin M et al. Use of psyschotropic medications in breastfeeding women. Birth Defects Res 2017;109:957-97.

https://doi.org/10.1002/bdr2.1077

64. Pizarro M, Fontenelle LF, Paravidino DC et al. An updated review of antidepressants with marked serotonergic effects in obsessive-compulsive disorder. Expert Opin Pharmacother 2014; 15(10):1391-401.

https://doi.org/10.1517/14656566.2014.914493

65. Guina J, Merrill B. Benzodiazepines I: Upping the Care on Downers: The Evidence of Risks, Benefits and Alternatives. J Clin Med 2018; 30;7(2):17. https://doi.org/10.3390/jcm7020017

66. Ross LE, Murray BJ, Steiner M. Sleep and perinatal mood disorders: a critical review. J Psychiatry Neurosci 2005; 30(4): 247-56.

67. Laela S, Anna KB, Mustikasar. Thought stopping and supportive therapy can reduce postpartum blues and anxiety parents of premature babies. Enferm Clin 2018; 28 Supl 1:126-9. https://doi.org/10.1016/S1130-8621(18)30051-2 


\title{
Terapija peripartalnih psihičkih poremećaja
}

\author{
Miodrag Stankovic ${ }^{1,2}$, Jelena Stojanov ${ }^{3}$, Jovana Antonijević ${ }^{1}$ \\ ${ }^{1}$ Univerzitet $u$ Nišu, Medicinski fakultet, Niš, Srbija \\ ${ }^{2}$ Centar za zaštitu mentalnog zdravlja, Klinički Centar Niš, Srbija \\ ${ }^{3}$ Specijalna bolnica za psihijatrijske bolesti "Gornja Toponica", Niš, Srbija
}

\begin{abstract}
SAŽETAK
Tokom peripartalnog perioda žene su pod većim rizikom za nastankom ili pogoršanjem već postojećih psihičkih poremećaja. Terapijske intervencije počivaju prvenstveno na psihoterapiji, a ukoliko su simptomi teški i predstavljaju opasnost za majku i dete razmatra se primena lekova, hospitalizacija ili elektrokonvulzivna terapija. Kognitivno-bihejvioralna psihoterapija je u prvoj terapijskoj liniji kod postpartalnog bluza i postpartalne depresije, paničnog poremećaja, generalizovanog anksioznog poremećaja i blagog do umerenog opsesivno-kompulzivnog poremećaja. Novija shvatanja u pogledu primene lekova postpartalno ukazuju da ih treba primenjivati ukoliko je rizik manji od komplikacija koje simptomi psihičkih poremećaja mogu izazvati. Iz grupe tricikličnih antidepresiva preporučuje se korišćenje nortriptilina ili desipramina, ali su se antidepresivi novijih generacija pokazali kao sigurniji tokom trudnoće. Fluvoksamin, paroksetin i sertralin se mogu koristiti postpartalno u periodu dojenja, dok fluoksetin i citalopram treba izbegavati. $U$ antepartalnom periodu preporučuje se primena antipsihotika prve generacije, haloperidola ili trifluorperazina, a od antipsihotika druge generacije kvetiapina, olanzapina, risperidona $i$ aripiprazola. Klozapin treba izbegavati u periodu dojenja. Primena psihostabilizatora tokom trudnoće zahteva dobro poznavanje vodiča, a postpartalno nisu preporučljivi ukoliko porodilja doji. Od benzodijazepina preporučuje se primena lorazepama. Svaki oblik terapijskog pristupa pokazuje se efikasnijim u prisustvu emocionalne podrške partnera i drugih članova porodice.
\end{abstract}

Ključne reči: peripartum, psihoterapija, farmakoterapija 